\title{
SAFE HARBOURS, CLOSED BORDERS? NEW ZEALAND \\ LEGAL AND POLICY RESPONSES TO CLIMATE DISPLACEMENT IN THE SOUTH PACIFIC
}

\author{
Vernon Rive, BA LLB LLM (Envir)(Auckland) \\ Senior Lecturer in Law, AUT Law School, Auckland, New Zealand.
}

\section{Introduction}

Amid recurrent media depictions of 'sinking islands' and scenarios of mass relocation of island communities from low-lying atolls, three consistent messages from Pacific peoples can be heard. The first is that for most, their wish and intention is to continue to live in their home countries despite the mounting effects of climate change with dignity, in safety and prosperity. ${ }^{1}$ Secondly, Pacific communities have no wish to relieve the international community of its obligations and commitments to reduce greenhouse gas emissions by offering large-scale migration from low-lying islands as 'the' solution to climate change within the region. Thirdly, migration should, if it is ultimately necessary, be undertaken in a planned, coordinated way, respecting and reflecting the resilience of people who are no strangers to re-establishing themselves in new environments in response to changing environmental conditions. This is what they have done for centuries.

For over 150 years, New Zealand has played a significant role in the South Pacific. Vibrant cultural, political, economic, and sporting interchanges reflect recognition amongst a broad cross-section of New Zealand society that its spiritual as well as geographic home is within the southern waters of the Pacific, rather than cities or fields of Europe. New Zealand hosts significant expatriate populations of Samoan, Tongan, Tuvaluan and others of Pacific origin. The ancestors of its indigenous Maori population traversed the Pacific Ocean to establish their home there.

Given its strong ties with other South Pacific nations, it would be natural to expect New Zealand's support role to flow into proactive planning, and legal and policy provision for responding to the effects of climate change in the Pacific. To an extent, it has. New Zealand is a significant donor to many Pacific countries. It has committed to on-going financial and technical support on climate change adaptation projects in a number of low-lying island states, including a recently announced five-year partnership to improve water security in Tuvalu, Tokelau, Kiribati, the Cook Islands and the Republic of the Marshall Islands. ${ }^{2}$

\footnotetext{
${ }^{1}$ For a recent discussion of the tension between the desire of residents of low-lying Pacific islands to remain in their home locations and the potential for migration see, for example Smith, R \& McNamara, K, 'Government discourses of climate change migration in Tuvalu and Kiribati', 8 July 2013, editorial on the website of the Asia-Pacific Migration and Environment Network

http://apmen.iom.int/en/m/editorials/item/141-government-discourses-of-climate-change-migration-intuvalu-and-kiribati

${ }^{2}$ New Zealand Prime Minister John Key news release 4 September 2013 'Clean water initiative for lowlying Pacific islands’ http://www.johnkey.co.nz/archives/1715-Clean-water-initiative-for-low-lying-Pacificislands.html
} 
New Zealand's support for in situ adaptation measures amongst its Pacific neighbours is not in real doubt. Its position on the more contentious aspect of climate change adaptation within the Pacific: whether, and to what extent, New Zealand would be willing to open its borders to climate change-displaced persons in the region less clear. ${ }^{3}$ This paper examines legal and policy issues arising out of the latter issue.

\section{Scale and pattern of climate change migration in the South Pacific}

An informed assessment of legal and policy issues associated with climate displacement in the South Pacific would logically build upon robust assessments of the scale and pattern of existing and predicted future climate-influenced migration and displacement in the region. However, despite sustained interest in this area by academics, non-governmental organisations (NGOs) and regional inter-governmental organizations for over ten years, there remains a dearth of information on, and considerable debate over, likely future migration and displacement flows which can be directly or indirectly attributed to the effects of climate change. ${ }^{4}$

In 2009, Waikato University geographer John Campbell estimated that there would be between 665,000 and $1.7 \mathrm{M}$ climate-displaced people in the Pacific by $2050 .^{5}$ A major 2012 study on existing and predicted future population movement in the Pacific commissioned by New Zealand's Department of Labour reached the conclusion that climate change represented a "threat to the livelihoods, security and well-being of Pacific people...which may force mass migrations”, however did not include any quantification of the potential numbers involved. ${ }^{6}$

\footnotetext{
3 It is noted at the outset that migration to 'developed' South Pacific countries such as New Zealand or Australia is by no means the only, or likely even to be the preferred option, in the event that citizens of low-lying Pacific countries are not able to remain in their home nations as a result of climate change impacts. As noted by Elliott \& Fagan, 'Some people have raised the possibility of expanded systems of migration to Australia and New Zealand, but Pacific leaders have suggested it might be more appropriate to call for support from Australia and New Zealand to help people resettle to other Pacific Islands. These islands may provide a more suitable cultural context for displaced rural communities.' M Elliot and D Fagan. "From Community to Copenhagen: Civil Society Action on Climate Change in the Pacific" in Bruce Burson (ed), Climate Change and Migration: South Pacific Perspectives (Wellington, IPS, 2009) at 75

${ }^{4}$ A leading New Zealand commentator on climate change related displacement and migration, Bruce Burson, recently observed, "The lack of acurate information on the possibel migratory consequnces of climate change impedes our ability to adequately prepare for and comprehensively respond to the humanitarian and protection needs of environmental migrants. Understanding more clearly the potential scale and patterns of climate change related migration is therefore the most pressing issue." Burson, B, 'Securing Meaningful International Agreement on Climate Change Related Displacement and Migration: The Refugee Convention as a Window on International Burden (Responsibility) - Sharing in an Involuntary Movement Context' in Climate Change and Displacement Reader (Scott Leckie, Ezekiel Simperingham and Jordan Bakker, eds., Taylor \& Francis, Routledge/Earthscan, 2012, at 159.

${ }^{5}$ Campbell, J, 'Pacific Island Populations 2009', Secretariat of the Pacific Community, Noumea, cited in Campbell, J 'Climate Change and Population Movement in Pacific Island Countries' in 'Climate Change and Migration: South Pacific Perspectives', Burson, B (ed), 2010, Institute of Policy Studies, Wellington at 12 at 38 .

${ }^{6}$ Bedford R and Hugo GJ (2012) Population Movement in the Pacific: A Perspective on Future Prospects. Department of Labour, New Zealand, at vi.
} 
In May 2013, conveners of the Nansen Initiative published a background report in preparation for consultative meetings involving representatives of Pacific nations and other stakeholders with an interest in displacement and migration implications of climate change in the region. In a similar vein to the 2012 New Zealand Department of Labour report, the authors of the Nansen background report noted that (for a range of reasons, including demographic, population, economic and environmental) "human mobility in the Pacific region is expected to significantly increase in the coming decades and beyond". ${ }^{7}$ No attempt was made however to arrive at quantitative estimates of numbers.

For the purpose of this paper, a related (and obvious) question is: what proportion of the number of climate-displaced persons within the South Pacific region may seek to be resettled within New Zealand? Attempted answers to that question are, at this stage, likely to be speculative. As far as the author is aware, no specific empirical investigations have taken place. What is known however, is that: New Zealand has significant expatriate communities of people of South Pacific origin whose members retain ongoing and strong links with relatives in their countries of historic origin $;^{8}$ empirical studies within South Pacific countries and in New Zealand indicate that New Zealand is seen as a natural and desirable destination for migration by some; 9 and a number of leaders of Pacific countries have identified New Zealand as a country whose assistance is sought to facilitate planned migration as one of a number of adaptive responses to the effects of climate change. ${ }^{10}$

\section{Protection deficit in international law}

\section{International conventions and documents}

There are a number of conventions and documents with potential relevance to the legal status and protection of persons displaced as a result of climate change, analysed extensively in the academic and NGO literature. They include: the 1951 Convention Relating to the Status of Refugees; ${ }^{11}$ the 1966 International Covenant on Civil and

\footnotetext{
${ }^{7}$ Background Paper: 'Human Mobility, Natural Disasters and Climate Change in the Pacific', May 2013, Nansen Initiative Secretariat, Geneva at 2.

${ }^{8}$ See: Shen, S, Gemenne, F "Contrasted Views on Environmental Change and Migration: the Case of Tuvaluan Migration to New Zealand," International Migration, Volume 49, Issue Supplement s1, 19 May 2011 (3000 Tuvaluan's estimated to reside in New Zealand). In January 2013, New Zealand's Ministry of Foreign Affairs and Trade recorded on its website 'There is a vibrant I-Kiribati community of over 2,000 people in New Zealand' http://www.mfat.govt.nz/Countries/Pacific/Kiribati.php. 2006 census statistics for other Pacific populations in New Zealand include: Samoan $(131,103)$; Cook Islands Maori $(58,008)$; Tongan (50, 481); Niuean (22,476), Fijian (9,864); Tokelauan (6,819).

${ }^{9}$ See, for example, Fedor, I. (2012). 'Cultural and National Identity in the Face of Climate Change: A Case Study of I-Kiribati Migrants in New Zealand' (Thesis, Master of Arts). University of Otago, at I; Shen, S, Gemenne, F, "Contrasted Views on Environmental Change and Migration: the Case of Tuvaluan Migration to New Zealand," International Migration, Volume 49, Issue Supplement s1, 19 May 2011, at 1.

${ }^{10}$ President Anote Tong of Kiribati has, to date, been the most vocal of Pacific leaders in this regard. For a statement of his office's position on relocation as one of a number of responses to the effects of climate change in Kiribati see http://www.climate.gov.ki/category/action/relocation/. For a useful recent analysis of contrasting views, see Smith, R, 'Should they stay or should they go? A discourse analysis of factors influencing relocation decisions among the outer islands of Tuvalu and Kiribati' Journal of New Zealand \& Pacific Studies, Volume 1, Number 1, 1 April 2013, pp. 23-39(17).

111951 Convention relating to the Status of Refugees (189 UNTS 137), in conjunction with 1967 Protocol relating to the Status of Refugees 606 UNTS 267. New Zealand acceded to the 1951 Convention on 30 June 1960 and to the 1967 Protocol on 6 August 1973.
} 
Political Rights; ${ }^{12}$ the 1966 International Covenant on Economic, Social and Cultural Rights; ${ }^{13}$ the 1954 Convention relating to the Status of Stateless Persons (not yet ratified by New Zealand); the 1961 Convention on the Reduction of Statelessness (ratified by New Zealand in 2006); the 1998 United Nations Guiding Principles on Internal Displacement; the 1992 United Nations Framework Convention on Climate Change (UNFCCC) and subsidiary instruments.

A detailed account of the arguments for and against the relevance and application of these instruments or documents to climate-displaced persons is beyond the scope of this paper. In summary however, none provide unequivocal binding direction on countries such as New Zealand concerning domestic obligations to assist the citizens of other states displaced as a result of climate change. ${ }^{14}$

\section{Regional instruments}

There are no existing legally binding regional conventions or treaties which address obligations of developed countries with the South Pacific region such as New Zealand towards their Pacific counterparts in the climate change context.

In 2008, members of the Pacific Islands Forum (PIF) signed what is known as the 'Niue Declaration', described at the time as 'the first ever climate change declaration for the region. ${ }^{15}$ The document records (non-binding) commitments of signatories to ongoing advocacy and support on regional and international climate change mitigation measures.

Notably (for the issues discussed in this paper), under the Niue Declaration, leaders of the PIF undertook to:

ENCOURAGE the Pacific's Development Partners to increase their technical and financial support for climate change action on adaptation, mitigation and, if necessary, relocation, while welcoming the pledged increases in resources to address the climate change challenge...

(emphasis added)

\footnotetext{
${ }^{12}$ International Covenant on Civil and Political Rights (1966) 999 UNTS 171.

13 International Covenant on Economic, Social and Cultural Rights (adopted 16 December 1966, entered into force 3 January 1976) 993 UNTS 3.

14 In Cancun in 2010, parties to the United Nations Framework Convention on Climate Change agreed to take 'measures to enhance understanding, coordination and cooperation with regard to climate-change induced displacement, migration and planned relocation, where appropriate, at the national, regional and international levels'. Notably, this has explicitly brought the issue of climate migration onto the UNFCCC agenda. However the agreement imposes no binding obligations on nations. It can be regarded as no more than a start to what may be a long process of negotiation within that forum. Conference of the Parties to the United Nations Framework Convention on Climate Change, Action Taken by the Conference of the Parties at its Sixteenth Session, (Addendum Pt 2 to the Report of the Conference of the Parties on its sixteenth session, held in Cancun from 29 November to 10 December 2010) FCCC/CP/2010/7/ Add.1, (15 March 2011) 5 ('COP16').
}

${ }^{15}$ Niue Declaration on Climate Change, 39 ${ }^{\text {th }}$ Pacific Islands Forum, Forum Communiqué Annex B (19-20 August 2008). 
Responding to threats from climate change on Pacific states was a central topic for discussion at the September 2013 meeting of the PIF in the Marshall Islands capital Majuro in September 2013. The widely publicised 'Majuro Declaration' was a key output of that meeting - a document which develops, with greater urgency, themes addressed five years earlier in Niue. ${ }^{16}$ Unsurprisingly, provisions of the Majuro Declaration highlight the need for, and commitment to, measures to 'urgently reduce and phase down greenhouse gas pollution in order to avert a climate crisis for present and future generations.' The need for support for adaptive measures is addressed, but the document omits the reference to 'relocation' made in the Niue Declaration:

In addition, we commit to accelerate and intensify our efforts to prepare for and adapt to the intensifying impacts of climate change, and to further develop and implement policies, strategies and legislative frameworks, with support where necessary, to climate-proof our essential physical infrastructure, adapt our key economic sectors and ensure climate-resilient sustainable development for present and future generations.

\section{New Zealand legal and policy framework}

Contrary to the (mis)understandings of an intriguing number of international commentators, ${ }^{17} \mathrm{New}$ Zealand has no specific immigration policies which, explicitly at least, are intended to address hardship and deprivation experienced in South Pacific nations as a result of climate change.

New Zealand does have a number of targeted immigration schemes which include capped quotas allowing defined groups from defined Pacific nations to participate in an annual ballot, and if successful, have the opportunity to then be considered against a number of other criteria (including language, income and work offer requirements). Most notably, they include the Pacific Access Category (PAC), the Samoan Quota and the Recognised Seasonal Employment (RSE) Scheme. Each of these schemes is well known by citizens of most Pacific nations, and the policies appear to be regarded as important practical and symbolic reflections of ties between New Zealand and Pacific nations. It is understood that all of the targeted schemes are fully subscribed. There are no indications however that the government is planning to increase target/quota numbers, whether in response to increased demand by an ever-growing South Pacific population, or in light of existing and predicted future drivers for migration and displacement associated with deteriorating environmental conditions because of climate change.

\section{Refugee status in New Zealand for climate displaced persons}

A number of cases have come before the New Zealand Immigration and Protection Tribunal (formerly, the Refugee Appeals Authority) involving applicants seeking refugee

\footnotetext{
${ }^{16}$ Majuro Declaration for Climate Leadership, 44 $4^{\text {th }}$ Pacific Islands Forum, Majuro, Marshall Islands (5 September 2013).

17 Jane McAdam lists a number of academic publications which perpetuate the error, noting that it appears that the misunderstanding was perpetuated by Al Gore's film, An Inconvenient Truth, in McAdam, J, 2011, 'Refusing 'Refuge' in the Pacific: (De)Constructing Climate-Induced Displacement in International Law', in Etienne Piguet, Antoine Pecoud \& Paul de Guchtenieree (ed.), Migration and Climate Change, Cambridge University Press/ UNESCO, Cambridge, footnote 86, at 18.
} 
status relying at least in part on hardship and deprivation in their home countries caused or contributed to by climate change. Consistent on this point with similar cases in Australia $^{18}$, the appeals have, without exception been unsuccessful.

In 2000, a group of appeals was heard by the New Zealand Refugee Appeals Authority (as it was then named) involving applications for refugee status from related appellants from Tuvalu. ${ }^{19}$ In similar terms, the Tuvaluan family members advanced grounds for refugee status in New Zealand, citing concern at rising sea levels which would exacerbate existing issues of inundation of the family home, together with poor medical facilities and the scarcity of employment opportunities within their home country. It was also submitted that 'the Tuvalu government failed in its duty of protecting the civil political, social, cultural and economic rights of the appellant for reasons of race (Tuvaluan), as nationals of Tuvalu (citizens) and as a member of a particular social group (defined as having no means to sustain themselves and survive).'

The RAA dismissed the appeals, holding: ${ }^{20}$

Clearly, none of the fears articulated by the appellant vis-à-vis his return to Tuvalu, can be said to be for reason of any one of the five Convention grounds in terms of the Refugee Convention, namely race, religion, nationality, membership of a particular group and political opinion. This is not a case where the appellant can be said to be differentially at risk of harm amounting to persecution due to any one of these five grounds. All Tuvalu citizens face the same environmental problems and economic difficulties living in Tuvalu.

In 2013, an appeal was brought to the successor of the RAA, the New Zealand Immigration and Protection Tribunal by a resident of Kiribati, also seeking asylum in New Zealand in large part due to deprivation resulting from adverse environmental conditions caused by climate change in his home country.

The decision of BL Burson, Member of the IPT, in the 2013 AF (Kiribati) ${ }^{21}$ case may well represent the most detailed legal analysis of an application for asylum on behalf of a climate-displaced person anywhere in the international refugee jurisprudence to date.

On behalf of the IPT, Burson accepted in its entirety, the evidence adduced on behalf of the i-Kiribati appellant relating to the physical and geographical vulnerability of Kiribati to existing and future effects of climate change, including rising sea levels, "risks to the land resource based livelihood of the people are from droughts, inundation of land from storm surges, salt water intrusion to water lenses, and excessive rainfall creating runoff into drinking groundwater wells", coastal erosion, deterioration of marine resources including coral reefs and fish stocks. ${ }^{22}$ In combination with growing population, general

\footnotetext{
${ }^{18}$ See footnote 21.

${ }^{19}$ Refugee Appeal No 72185 (10 August 2000); Refugee Appeal No 72186 (10 August 2000); Refugee Appeal Nos 72189-72195 (17 August 2000); Refugee Appeal Nos 72179-72181 (31 August 2000); Refugee Appeal No 72313 (19 October 2000); Refugee Appeal No 72314 (19 October 2000); Refugee Appeal No 72315 (19 October 2000); Refugee Appeal No 72316 (19 October 2000).

${ }^{20}$ Refugee Appeal No 72185 (10 August 2000) at para [16].

${ }^{21}$ AF (Kiribati) [2013] NZIPT 800413.

22 At para [38], it is recorded 'The Tribunal finds the appellant to be credible. His account was told
} 
economic conditions, the IPT accepted without demur the significant hardships already being experienced by residents of the low-lying atolls, as well as predicted future difficulties that will arise as the range of effects of climate change make themselves known with increasing intensity in Kiribati.

Consistent with previous New Zealand ${ }^{23}$ and Australian decisions, ${ }^{24}$ the IPT dismissed the appeal. On the central claim for refugee status under the 1951 Convention, the IPT held: 25

..the appellant's claim under the Refugee Convention must necessarily fail because the effects of environmental degradation on his standard of living were, by his own admission, faced by the population generally. The sad reality is that the environmental degradation caused by both slow and sudden onset natural disasters is one which is faced by the Kiribati population generally.

A parallel submission that denying the appellant's asylum in New Zealand (thus requiring him to return to Kiribati) would contravene Article 6 of the ICCPR (the 'right to life') was also rejected: ${ }^{26}$

... the risk to the appellant and his family still falls well short of the threshold required to establish substantial grounds for believing that they would be in danger of arbitrary deprivation of life within the scope of Article 6. It remains firmly in the realm of conjecture or surmise.

In dismissing the appeal, the IPT took care to make it clear that the decision should not be regarded as definitively rejecting the potential for refugee or protection status under New Zealand or international law in all instances where displacement has or will occur in circumstances involving the effect of climate change. The decision contains an impressive analysis of climate change-influenced displacement under international refugee and human rights law, and careful qualification of its findings. ${ }^{27}$

Nevertheless the decision confirms the position already taken in previous New Zealand refugee appeals, international case law and academic commentary, namely that under New Zealand's existing legal regime for refugees and immigrants (itself built upon the existing international law in this area), only in the most exceptional circumstances will persons displaced as a result of climate change be entitled to legal recognition as refugees or protected persons.

New Zealand government policy development

In summary, under the existing international and domestic legal and policy framework, persons seeking refuge in New Zealand from the worst impacts of climate change in the

candidly and openly. It is accepted in its entirety.'

${ }^{23}$ Refugee Appeal No 72185 (10 August 2000); Refugee Appeal No 72186 (10 August 2000); Refugee Appeal Nos 72189-72195 (17 August 2000); Refugee Appeal Nos 72179-72181 (31 August 2000); Refugee Appeal No 72313 (19 October 2000); Refugee Appeal No 72314 (19 October 2000); Refugee Appeal No 72315 (19 October 2000); Refugee Appeal No 72316 (19 October 2000); BG (Fiji) [2012] NZIPT 800091.

24 For example, 0907346 [2009] RRTA 1168 (10 December 2009).

${ }^{25} A F$ (Kiribati) [2013] NZIPT 800413, at [75].

${ }^{26}$ AF (Kiribati) [2013] NZIPT 800413, at [91].

${ }^{27}$ See, in particular, paras [56] - [65]. 
South Pacific have no clear legal avenues available to them. Existing immigration schemes such as the PAC, Samoan Quota and RSE may provide opportunities for some seeking temporary or permanent residence in New Zealand. However, those schemes require pre-arranged employment with minimum obligations for financial support. They are also tightly controlled in terms of annual quotas.

There is no obvious sign of any existing or imminent 'wave' of would-be migrants to New Zealand from the South Pacific. However despite the lack of empirical analysis on the likely future migration flows within the South Pacific as a result of climate changerelated effects, it is not especially controversial that by 2050, large numbers of South Pacific residents will have been displaced as a result of a combination of population and environmental factors. It would be naïve, given New Zealand's existing strong ties with its South Pacific neighbours, to expect anything other than a significant increase in the numbers of Pacific residents seeking refuge in the relatively climate-change buffered environment of New Zealand. ${ }^{28}$

One might expect that the New Zealand government would be actively considering the implications from a legal, policy and practical perspective of future migration and displacement scenarios within the region. ${ }^{29}$ Is it happening?

In a 2011 article, Australian academic Jane McAdam cited a 2008 New Zealand Ministry of Foreign Affairs and Trade (MFAT) document as evidence of a 'revised' approach towards the issue of 'environmental migrants' in the South Pacific. ${ }^{30}$ According to the MFAT document, New Zealand's new focus would be to:

a) acknowledge the concerns of Pacific Island countries in relation to this issue; b) stress that current climate change efforts in the Pacific should continue to focus on adaptation, and should be underpinned by the desire of Pacific peoples to continue to live in their own countries; and

c) reaffirm that New Zealand has a proven history of providing assistance where needed in the Pacific, and that our approach to environmentally displaced persons would be consistent with this.

.. This includes a commitment to 'respond to climatic disasters in the Pacific and manage changes as they arise.'

In March 2013, the author lodged a request under the Official Information Act 1982 (OIA) seeking a formal response as to whether there had been any further consideration

\footnotetext{
${ }^{28}$ For a summary of anticipated climate change impacts on New Zealand, see Rive, V \& Weeks, T 'Adaptation to Climate Change in New Zealand' in A Cameron (ed) 'Climate Change Law and Policy in New Zealand' (LexisNexis, Wellington, 2011) at ch 9, section 6.4.

${ }^{29}$ In 1990, the authors of a report representing the outcome of a six-month, prime ministerial-initiated study of New Zealand's relationship with Pacific nations noted "There is widespread concern in the region about the potentially profound effects of climate change, and especially a sea level rise would have on Pacific Island countries ...the region faces a major potential problem of environmental refugees." Amongst its recommendations were "That early consultations be held with the Governments of Kiribati and Tuvalu about the means by which their people might make up a greater proportion of Pacific Island immigrants." South Pacific Policy Review Group (1990) 'Towards a Pacific Island Community' Wellington.

${ }^{30}$ McAdam, J, 2011, 'Refusing 'Refuge' in the Pacific: (De)Constructing Climate-Induced Displacement in International Law', in Etienne Piguet, Antoine Pecoud \& Paul de Guchtenieree (ed.), Migration and Climate Change, Cambridge University Press / UNESCO, Cambridge.
} 
given to New Zealand's legal and policy response to issues of climate-contributed displacement or migration within the South Pacific. Officials from MFAT and Ministry of Pacific Affairs were also interviewed.

In response to the March 2013 OIA, a number of internal briefing and policy documents were provided. They confirm, in summary, that New Zealand's domestic policy (and international positioning) on the issue of climate-displaced persons within the South Pacific has not advanced in any meaningful sense from the 'revised approach' adopted in 2008, reported by McAdam. In a 2009 policy paper, MFAT and Department of Labour officials advised their Ministers: ${ }^{31}$

“...New Zealand's existing immigration policy settings are sufficiently flexible that they may be able to form one response to this issue, should it become a reality in future. Pacific migrants can currently enter New Zealand through general immigration policies, such as those for skilled migrants, temporary workers or family sponsorship. There are also immigration policies specifically for Pacific countries, such as the Pacific Access Category (for migrants from Tuvalu, Kiribati and Tonga); the Samoan Quota and Recognised Seasonal Employer (RSE) Scheme.

None of these policies were developed in response to climate change or climate induced migration although they could potentially be helpful in responding to it as part of a broader toolkit of policy options in which adaptation and mitigation options are given priority..."

\section{A January 2013 MFAT briefing paper to the Associate Climate Change Minister} expanded on the theme: ${ }^{32}$

"New Zealand's policy on the issue of 'environmental refugees' remains under review. Such 'refugees' have no current status under international law... New Zealand has indicated that it will continue to respond to climatic disasters in the Pacific and manage changes as they arise...

Media reporting that New Zealand has agreed to take 'environmental refugees' from Tuvalu... is incorrect. There is no such policy. However New Zealand will continue to monitor the situation and provide climate change assistance and disaster relief as it has always done."

Queried on the reference to New Zealand's policy remaining 'under review', in a telephone interview on 28 May 2013, an MFAT official advised: ${ }^{33}$

I think that in that context, I wouldn't want to imply that we have a grand process ... it's more like, we are keeping a watch on it... that if things change or we judge that we may

\footnotetext{
${ }^{31}$ Joint Ministry of Foreign Affairs and Trade and Department of Labour submission to the Ministers of Foreign and Immigration 22 July 2009, released to the author under the Official Information Act 1982 in May 2013.

${ }^{32}$ Ministry of Foreign Affairs and Trade briefing to the Associate Minister of Climate Change, January 2013 released to the author under the Official Information Act 1982 in May 2013.

33 Telephone interview by the author of Mr Roger Dungan, Senior Policy Officer Climate Change Environment Division, New Zealand Ministry of Foreign Affairs \& Trade, 28 May 2013.
} 
need to refer to Ministers for more guidance, or whatever, then we will. To say it is "under review" doesn't mean that it is "under active review". But it is not like the case is closed, and our policy is done and dusted. It is certainly a living thing, and we keep our eye on developments, that if something did come up that we needed to get some guidance or make recommendations to ministers on, then we would certainly do so.

It is apparent that the government agency with responsibility for policy development on New Zealand's response to climate-displacement in the South Pacific - MFAT - has not updated its policy since 2008, has no active working groups looking at the issue, and as recently as May 2013 has explicitly reconfirmed its position not to reassess its policy settings. ${ }^{34}$ This is despite:

- An open call for New Zealand (as one of the 'Pacific's Development Partners') to 'increase [its] technical and financial support for climate change action on adaptation, mitigation and, if necessary, relocation' in the 2008 Niue Declaration; ${ }^{35}$

- The issue of responses to climate displacement having been openly placed on the agenda for international consideration in a decision of the conference of parties to the UNFCCC in Cancun in 2010; ${ }^{36}$

- Direct calls by Pacific leaders for engagement by New Zealand and Australia in consideration of a framework and process for planned migration-as-adaptation as part of a wider package of measures to address the impact of climate change on low-lying island states within the South Pacific. ${ }^{37}$

\section{Options and opportunities}

Over the past 10 years as issues of the potential magnitude and distribution of climatedisplaced people have begun to enter public consciousness through media reports and NGO awareness-raising, there has been an exponential growth in academic analysis and public policy consideration of various legal and policy responses to the issue.

\section{New or modified existing multi-lateral instruments?}

A range of possible solutions or responses to the 'protection deficit' at international law for climate-displaced persons has been developed and discussed in the literature, including:

- Amending the 1951 Refugee Convention to specifically cover cross-border displacement as a result of environmental/climate change-caused degradation;

\footnotetext{
${ }^{34}$ Compare the observations in Hausler, K \& McCorquodale, R (2011): Climate change and its impact on security and survival, Commonwealth Law Bulletin, 37:4, 617-627; McAdam, J, 2011, 'Refusing 'Refuge' in the Pacific: (De)Constructing Climate-Induced Displacement in International Law', in Etienne Piguet, Antoine Pecoud \& Paul de Guchtenieree (ed.), Migration and Climate Change, Cambridge University Press / UNESCO, Cambridge, pp. 102 - 137 which indicate that the New Zealand government is in the process of developing a specific policy on Pacific climate migrants. It is not apparent to the author that this is the case.

${ }^{35}$ Niue Declaration on Climate Change, $39^{\text {th }}$ Pacific Islands Forum, Forum Communiqué Annex B (19-20 August 2008).

${ }^{36}$ See footnote 14 .

${ }^{37}$ See, for example (in relation to Kiribati President Anote Tong), McAdam, J, 2011, 'Refusing 'Refuge' in the Pacific: (De)Constructing Climate-Induced Displacement in International Law', in Etienne Piguet, Antoine Pecoud \& Paul de Guchtenieree (ed.), Migration and Climate Change, Cambridge University Press / UNESCO, Cambridge at footnote 76.
} 
- Developing a new, stand-alone multilateral treaty or convention on climate change/environmental displacement; ${ }^{38}$

- Developing a new protocol to the UNFCCC which specifically addresses climate change displacement.

A detailed assessment of the merits of the multilateral instrument options listed above is beyond the scope of this paper. Briefly, the author:

- shares the strong reservations expressed by a number of commentators concerning suggested redrafting or supplementing the 1951 Refugee Convention in order to confer refugee or protect person status on persons displaced for environmental or climate change-related reasons; ${ }^{39}$

- concurs with the views expressed by McAdam and others regarding the shortmedium term practical and political impediments to negotiation of an effective stand-alone multilateral treaty or convention addressing climate change/environmental displacement, while not ruling out entirely the possibility of such an international instrument being developed in the fullness of time;

- sees potential for some sort of multilateral framework for coordinating state and regional arrangements and responses for climate change-related displacement to be included in future UNFCCC instruments or decisions, however doubts that in the short-medium term, a full-blown dedicated protocol is likely to be politically or practically feasible.

\section{Regional solutions?}

Coordinated regional arrangements, whether recorded in 'hard law' instruments or 'soft law' declarations or statements offer a number of distinct advantages over fully multilateral negotiated outcomes. In the climate displacement context, this is particularly the case for a number of reasons. Firstly, there is the pragmatic issue of reaching a meaningful agreement which contains sufficient specificity and relevance to usefully guide the development of domestic emigration/immigration, protection and other support processes. As has been rightly noted by a number of commentators, for an issue likely to be as politically contentious and sensitive as immigration and refugee policy, the prospects of achieving consensus on the large number of issues that would need to be addressed in such a document within a workable timeframe can only be regarded as wildly optimistic.

On the other hand, documented agreed regional arrangements (while still likely to be challenging politically for the same reasons as those noted above) would appear to have

\footnotetext{
${ }^{38}$ See, for example, Docherty, B \& Giannini, T, 'Confronting a Rising Tide: A Proposal for a Convention on Climate Change Refugees' (2009) 33 Harv. Envtl. L. Rev. 349; Hodkinson, D et al, 'Hour When the Ship Comes in: A Convention for Persons Displaced by Climate-change' (2009) accessible at www.ccdpconvention.com.

${ }^{39}$ See, for example McAdam, J, 2011, 'Refusing 'Refuge' in the Pacific: (De)Constructing ClimateInduced Displacement in International Law', in Etienne Piguet, Antoine Pecoud \& Paul de Guchtenieree (ed.), Migration and Climate Change, Cambridge University Press/ UNESCO, Cambridge, at 13-14; Burson, B, 'Securing meaninful international agreement on climate change related displacement and migration: The Refugee Convention as a Window on International Burden (Responsibility) - Sharing in an Involuntary Movement Context' in Climate Change and Displacement Reader (Scott Leckie, Ezekiel Simperingham and Jordan Bakker, eds., Taylor \& Francis, Routledge/Earthscan, 2012, at 167.
} 
better prospects of success, especially if negotiated through existing regional fora and if they build upon existing regional arrangements, including institutional as well as legal and political affirmations of shared policy objectives.

In the South Pacific context, the Pacific Islands Forum has the question of regional responses to climate displacement already on its agenda and, no doubt, would be central to the development of a coordinated regional response.

The Swiss and Norwegian-led Nansen Initiative, a "state-led, bottom-up consultative process...intended to build consensus on the development of a protection agenda addressing the needs of people displaced across international borders by natural disasters, including the effects of climate change" held the first of a planned series of five regional consultations in Rarotonga in May 2013. ${ }^{40}$ The New Zealand government was represented at the event.

The outcome document from that consultation exercise records agreement amongst participants that: ${ }^{41}$

- "As a consequence of sea level rise, acidification and more extreme weather patterns, voluntary migration, planned relocation and forced displacement are expected to rise significantly in the next decades and beyond";

- "In the context of natural disasters and climate change these developments require action and resource mobilization to be taken at community, national, regional and international levels;

Regional actions agreed as necessary included

- "Continue the regional dialogue on voluntary migration, forced displacement and planned relocation"; and

- "Develop appropriate normative frameworks to address the protection needs of displaced or relocated populations, including temporary protection schemes or template agreements, which take into account lessons from past experience and incorporate existing good practices from the Pacific Island countries.

It will be interesting to observe the New Zealand government's response, in particular to the second action point noted above.

\section{Conclusions}

For compelling historical, cultural and social reasons, most residents of Pacific nations at risk from the effects of climate change regard remaining where they are, and developing adaptive solutions to issues such as rising sea level and increased exposure to weather events, as their first priority.

However, it is clearly the case that migration - whether that is to other, closer, Pacific neighbours such as Fiji, or to countries such as Australia and New Zealand where more

\footnotetext{
$4^{0}$ For a thoughtful assessment of the potential for the Nansen Initiative to facilitate solutions in relation to climate displacement, see Kälin, W, 'From the Nansen Principles to the Nansen Initiative' FMR 41 December 2012 at 48.

${ }^{41}$ Nansen Initiative, 'Conclusions: Nansen Initiative Pacific Regional Consultation', Undated (recording outcome of meetings in Rarotonga from 21 to 24 May 2013), Nansen Initiative Secretariat, Geneva.
} 
favourable employment and other opportunities likely to exist - is not only under contemplation, but is also a predictable and rational response as part of a wider set of potential adaptive responses to the effects of climate change in the region.

To date, despite rhetorical support for its Pacific neighbours, the New Zealand government has not actively engaged with legal, policy or practical implications of likely significant future flows of climate change-related migration to its shores. Its current policy, if it can be described as such, is not substantively more than a vague commitment to 'wait and see.' No doubt this is convenient in terms of existing domestic politics. But a failure to plan now will have lasting adverse consequences which, it is suggested, New Zealand, as well as its Pacific neighbours, will come to regret. 